\title{
Life cycle, population dynamics, growth and production of Abra segmentum (Mollusca, Bivalvia) at low salinities in a Mediterranean lagoon
}

\author{
Theodoros Kevrekidis · K. Kasapis • \\ V. Kalpia
}

Received: 6 July 2008/Revised: 11 February 2009/Accepted: 27 February 2009/Published online: 22 March 2009

(C) Springer-Verlag and AWI 2009

\begin{abstract}
Aspects of the biology of Abra segmentum were investigated at low salinities in a Mediterranean coastal lagoon (Monolimni Lagoon, Northern Aegean Sea). Monthly samples were collected during the period from February 1998 to January 1999. Recruitment occurred from mid-spring to early autumn $(0.3-5.7 \mathrm{psu})$ and recruits grew during summer and autumn (1.2-5.7 psu), while a major part vanished during next autumn, displaying a maximum life span of about 20 months. A positive correlation was found between the percentage of individuals having a shell length of $\leq 3.5 \mathrm{~mm}$ and temperature; age group 0 showed a growth rate of $0.97 \mathrm{~mm}$ per month, and the largest individual collected had a $19.76 \mathrm{~mm}$ shell length. The population density sharply increased during late spring $(0.3-1.2 \mathrm{psu})$; this increase was followed by a decline during summer and, afterwards, a gradual increase up to late autumn. Secondary production calculated by the size-frequency method gave a mean annual density $(n)$ of 3,357 individuals $\mathrm{m}^{-2}$, a mean annual biomass $(B)$ of $21.98 \mathrm{~g} \mathrm{DW} \mathrm{m}^{-2}$, an annual production $(P)$ of $73.72 \mathrm{~g} \mathrm{DW} \mathrm{m}^{-2}$ and a $P: B$ ratio of 3.35. A comparison of the present data with available data of A. segmentum populations from higher salinity habitats revealed that this bivalve in the study area showed a life history pattern similar to that of other populations of the species and a comparatively high
\end{abstract}

Communicated by H.-D. Franke.

T. Kevrekidis $(\bowtie) \cdot$ K. Kasapis · V. Kalpia Laboratory of Environmental Research and Education, Democritus University of Thrace, Nea Hili, 68100 Alexandroupolis, Greece

e-mail: tkebreki@eled.duth.gr growth rate, maximum body size, $n, B, P$ and $P: B$ ratio. Our findings suggest that the studied aspects of $A$. segmentum biology could not be markedly affected by low salinities.

Keywords Macroinvertebrate - Population dynamics . Growth $\cdot$ Production · Salinity

\section{Introduction}

The bivalve Abra segmentum (Recluz, 1843) [A. ovata (Philippi, 1836)] is a shallow-water species with a geographical range extending from the Atlantic coasts of Morocco and France to the Mediterranean Sea, the Black Sea, the Caspian Sea and the Aral Sea (e.g. Denis 1981; Kiseleva et al. 1996; Aladin et al. 1998; Latypov 2004; Nicolaidou et al. 2006). This infaunal, deposit-feeding bivalve is a very euryhaline species living in waters, which vary from oligohaline to hyperhaline (e.g. Marazanof 1969; Grémare et al. 2004; Kevrekidis 2004). Abra segmentum is a common and frequently abundant species in the Mediterranean coastal lagoons, playing a dominant role, both in numbers and biomass, in the infauna of these habitats and forming an important food for fish (e.g. Cottiglia et al. 1983; Kevrekidis et al. 1990; Kevrekidis 2004; Nicolaidou et al. 2006; Ponti et al. 2007). In addition, this bivalve, reaching high densities and displaying a high sediment reworking rate per individual, may account for a significant part of sediment reworking occurring in Mediterranean lagoons (e.g. Maire et al. 2007).

Because of its significant role in brackish-water coastal ecosystems, A. segmentum has become one of the most intensively studied macroinvertebrate species in these 
environments. Research topics involve, among others, reproductive biology, life history, demography, growth, population dynamics and secondary production (e.g. Denis 1981; Guelorget and Mazoyer-Mayere 1982; Bachelet et al. 1986; Nicolaidou and Kostaki-Apostolopoulou 1988; Kevrekidis and Koukouras 1992; Sprung 1994; Reizopoulou and Nicolaidou 2007). However, to our knowledge, these aspects of the biology and ecology of A. segmentum have been studied in mesohaline, polyhaline or/and euhaline environments, but not at extremely low salinity habitats; sub-lethal salinities may be important physiological constraints on reproduction and growth and determinants of life history patterns and population dynamics of macrobenthic invertebrates in brackish water habitats (e.g. Cunha et al. 2000).

The present study aims: (1) to describe the demography, growth, population dynamics and production of Abra segmentum at extremely low salinities $(0.5-5.5 \mathrm{psu})$ in a Mediterranean coastal lagoon (Monolimni Lagoon, Northern Aegean Sea), (2) to investigate the key environmental variables affecting life history traits and population dynamics of this bivalve and (3) to compare the present data with available data for other populations of the species from higher salinity coastal habitats. Provided that (1) physiological adaptations of macroinvertebrates to suboptimal environmental conditions, such as osmoregulatory adaptation, require energetic costs that may only allow a decreased allocation of energy for growth and reproduction (Neuparth et al. 2002), (2) the energetic trade-off between these physiological needs may have consequences for the life history of the species (Neuparth et al. 2002), and (3) especially at salinities lower than 5-7 psu, energy expenses are high and, in addition, the nutritive absorption efficiency is low (Normant \& Lamprecht, 2006), we predict that recruitment, growth, life history pattern, population density and dynamics and production of $A$. segmentum in the study area will be affected negatively to a significant extent by the extremely low salinities.

\section{Materials and methods}

Study area

The Evros Delta is located at the northeastern part of the Aegean Sea. Fresh water flows into the delta area through both the eastern and western branches of Evros River as well as through both the streams Mikri Maritsa and Loutron. Three islets and some lagoons have been formed in the delta area. Monolimni (or Paloukia) Lagoon occupying an area of about $1.12 \mathrm{~km}^{2}$ communicates with the sea mainly through a $15 \mathrm{~m}$ wide opening at its NW end.

In July 1997, water salinity near the bottom varied between 30.0 and 31.5 psu overall in the Monolimni Lagoon. An increased freshwater inflow during winter and spring of 1998 following a period of intense rainfall on the river catchment area resulted in a sharp decline in salinity values during February 1998-January 1999. At site $B_{2}$, located in the innermost northern part of this lagoon, water depth fluctuated between 30 and $50 \mathrm{~cm}$, and salinity, dissolved oxygen, oxygen saturation, $\mathrm{pH}$ and temperature near the bottom varied between 0.3 and $5.7 \mathrm{psu}, 9.78$ and $18 \mathrm{mg} \mathrm{l}^{-1}, 101$ and $220 \%, 7.45$ and 9.32 and $4.2^{\circ}$ and $28.5^{\circ} \mathrm{C}$, respectively, during February $1998-\mathrm{January} 1999$; the sediment was very fine sand, while sediment temperature at a depth of 1 and $5 \mathrm{~cm}$ and sediment organic matter varied between 3.7 and $27^{\circ} \mathrm{C}, 3.5$ and $28.6^{\circ} \mathrm{C}$ and 0.48 and $2.20 \%$, respectively (Kevrekidis 2004). The monthly variation in salinity, water temperature, sediment temperature at 1 and $5 \mathrm{~cm}$ and sediment organic matter at site $\mathrm{B}_{2}$ during this period is shown in Table 1.

Table 1 Monthly variation in physico-chemical parameters of water and sediment at station B $_{2}$ during February 1998-January 1999 (after Kevrekidis 2004)

\begin{tabular}{|c|c|c|c|c|c|c|c|c|c|c|c|c|}
\hline & $\begin{array}{l}\text { February } \\
1998\end{array}$ & March & April & May & June & July & August & September & October & November & December & $\begin{array}{l}\text { January } \\
1999\end{array}$ \\
\hline \multicolumn{13}{|l|}{ Water } \\
\hline Salinity (psu) & 0.8 & 0.3 & 0.3 & 1.2 & 1.3 & 2.8 & 5.6 & 5.7 & 4.6 & 3.0 & 1.7 & 0.7 \\
\hline Temperature $\left({ }^{\circ} \mathrm{C}\right)$ & 9.2 & 8.2 & 17.4 & 16.7 & 26.6 & 28.5 & 26.5 & 23.1 & 17.8 & 10.2 & 4.2 & 8.6 \\
\hline \multicolumn{13}{|l|}{ Sediment } \\
\hline $\begin{array}{l}\text { Temperature } \\
\text { at } 1 \mathrm{~cm}\left({ }^{\circ} \mathrm{C}\right)\end{array}$ & 8.5 & 8.2 & 16.7 & 16.7 & 27 & 26.7 & 24.5 & 24.0 & 17.2 & 11.4 & 3.7 & 8.5 \\
\hline $\begin{array}{l}\text { Temperature } \\
\text { at } 5 \mathrm{~cm}\left({ }^{\circ} \mathrm{C}\right)\end{array}$ & 8.1 & 7.6 & 16.0 & 16.7 & 26.0 & 28.6 & 23.5 & 21.9 & 16.4 & 11.2 & 3.5 & 8.1 \\
\hline Organic matter $(\%)$ & 0.48 & 0.93 & 0.75 & 0.90 & 2.20 & 1.00 & 1.09 & 1.36 & 1.43 & 0.98 & 0.84 & 0.82 \\
\hline
\end{tabular}


The structure of the macrozoobenthic assemblage at site $\mathrm{B}_{2}$ in Monolimni Lagoon throughout February 1998-January 1999 has been described by Kevrekidis (2004). A meadow of the submerged angiosperm Ruppia maritima L. occurred in the innermost part of the lagoon, while macroalgae were occasionally observed; the biomass of $R$. maritima almost continuously increased from May to October 1998 (Malea et al., 2004). An annual fishing production of $11100 \mathrm{~kg}$, primarily consisting of Mugilidae was recorded in Monolimni Lagoon in 1998, according to the local fishery service.

\section{Data collection and analyses}

Monthly samples of macrobenthic fauna were collected during February 1998-January 1999 at the sampling station $\mathrm{B}_{2}$ located at the innermost northern part of the Monolimni Lagoon $\left(40^{\circ} 46^{\prime} \mathrm{N}, 26^{\circ} 03^{\prime} \mathrm{E}\right)$. Four random sampling units were taken each time with a Van Veen special sampler with handles (Larimore 1970); the sampler covered a surface of $400 \mathrm{~cm}^{2}(20 \times 20 \mathrm{~cm})$ and penetrated to a depth of $20 \mathrm{~cm}$. The samples were sieved with a $500 \mu \mathrm{m}$ sieve and the animals were kept in a $5 \%$ formalin solution. For further details on sampling, see Kevrekidis (2004).

In the laboratory, the specimens of A. segmentum were separated from the remaining macrobenthos. The shell length $(L)$ of the specimens was measured with a vernier caliper to the nearest $0.02 \mathrm{~mm}$, while that of small ones with the aid of an eyepiece micrometer under a stereomicroscope to the nearest $0.025 \mathrm{~mm}$. For the estimation of dry body weight $(W)$, the shell of the animals was removed or, for the smaller ones, was decalcified in a $2 \mathrm{~N}$ solution of $\mathrm{HCl}$. The animals were then dried in an oven for $48 \mathrm{~h}$ at $105^{\circ} \mathrm{C}$ and weighed to the nearest $0.0001 \mathrm{~g}$.

On the basis of shell length, individuals were aggregated into 1-mm size classes. The population was analysed by the graphical analysis of polymodal frequency distributions (Harding 1949). Spearman's rank correlation coefficient $(\rho)$ was applied to identify significant correlations. Searching for the best description of the relation between shell length $(L)$ and dry body weight $(W)$, the equation $W=b L^{\alpha}$ (where $\alpha$ and $b$ are constants) was chosen, which showed the highest positive coefficient of correlation; so, the simple allometric formula was transformed as follows: $\log _{10} W=\alpha \log _{10} L+\log _{10} b$. A $t$ test was used to examine wether the relationship between shell length and dry body weight differs from isometry.

Annual production was calculated by the size frequency Hynes' method, since it was not possible to discriminate accurately the different overlapping cohorts. The largest size-classes, which had a very low number of individuals, were grouped, since a possible overestimate by Hynes' method might be caused by the very low numbers of individuals in the largest size groups. The formula used was Hynes' formula as given by Menzies (1980):

$P=\left[i \sum_{j=1}^{i}\left(n_{j}-n_{j+1}\right) \times\left(W_{j} W_{j+1}\right)^{1 / 2}\right] \times 365 / \mathrm{CPI}$

where $i$ : the number of size-classes or "times loss" factor; $n_{j}$ : the mean number of individuals in size-class $j ; W_{j}$ : the mean weight of an individual in the $j$ th size-class; $\left(W_{j} W_{j+1}\right)^{1 / 2}$ : the geometric mean weight between two size-classes and CPI: the cohort production interval in days.

\section{Results}

Population structure and growth

The population structure of $A$. segmentum at station $\mathrm{B}_{2}$ for each sampling date is shown in Fig. 1 as length-frequency histograms. The smallest individual found had a shell length of $0.93 \mathrm{~mm}$. Individuals of the smallest size class $(0.5-1.5 \mathrm{~mm})$ were collected during April to September, while, in addition, the percentage of the individuals having a shell length of $\leq 3.5 \mathrm{~mm}$ was also highest during the same period (Fig. 1), suggesting that recruitment occurred mainly from mid-spring to early autumn. A positive correlation was found between the percentage of the individuals having a shell length of $\leq 3.5 \mathrm{~mm}$ and water temperature and sediment temperature at 1 and $5 \mathrm{~cm}$ depth (Table 2). During April to September, the water temperature varied between 16.7 and $28.5^{\circ} \mathrm{C}$ and water salinity between 0.3 and $5.7 \mathrm{psu}$, while during the previous period (February-March), these environmental variables fluctuated between 8.2 and $9.2^{\circ} \mathrm{C}$ and 0.3 and 0.8 psu. The largest $A$. segmentum individuals having a shell length of 19.76, 18.86 and $18.02 \mathrm{~mm}$ were found during September, August and July, respectively (Fig. 1).

Development in time of the main size groups of $A$. segmentum delimited by means of graphical analysis of the frequency distribution is given in Fig. 2. Size group A can be characterized as age group 0 . This group was first observed in May, composed of small individuals having a mean shell length of $1.2 \mathrm{~mm}$. It dominated the population mainly from August onwards, while it constituted almost the entire population during November to January (Fig. 2).

Growth in shell length of this age group was constant during May to November (mean shell length: $7.0 \mathrm{~mm}$; Fig. 2), with a rate of $0.97 \mathrm{~mm}$ per month. During this period, water temperature, salinity and sediment organic matter had generally their highest values $\left(10.2-28.5^{\circ} \mathrm{C}\right.$, $1.2-5.7$ psu and $0.90-2.20 \%$, respectively), while during 
Fig. 1 Size frequency histograms of Abra segmentum from 13 February 1998 to 17 January 1999 at station $B_{2}$ in Monolimni lagoon, Evros River Delta (N.Aegean Sea).

$n$ number of specimens measured
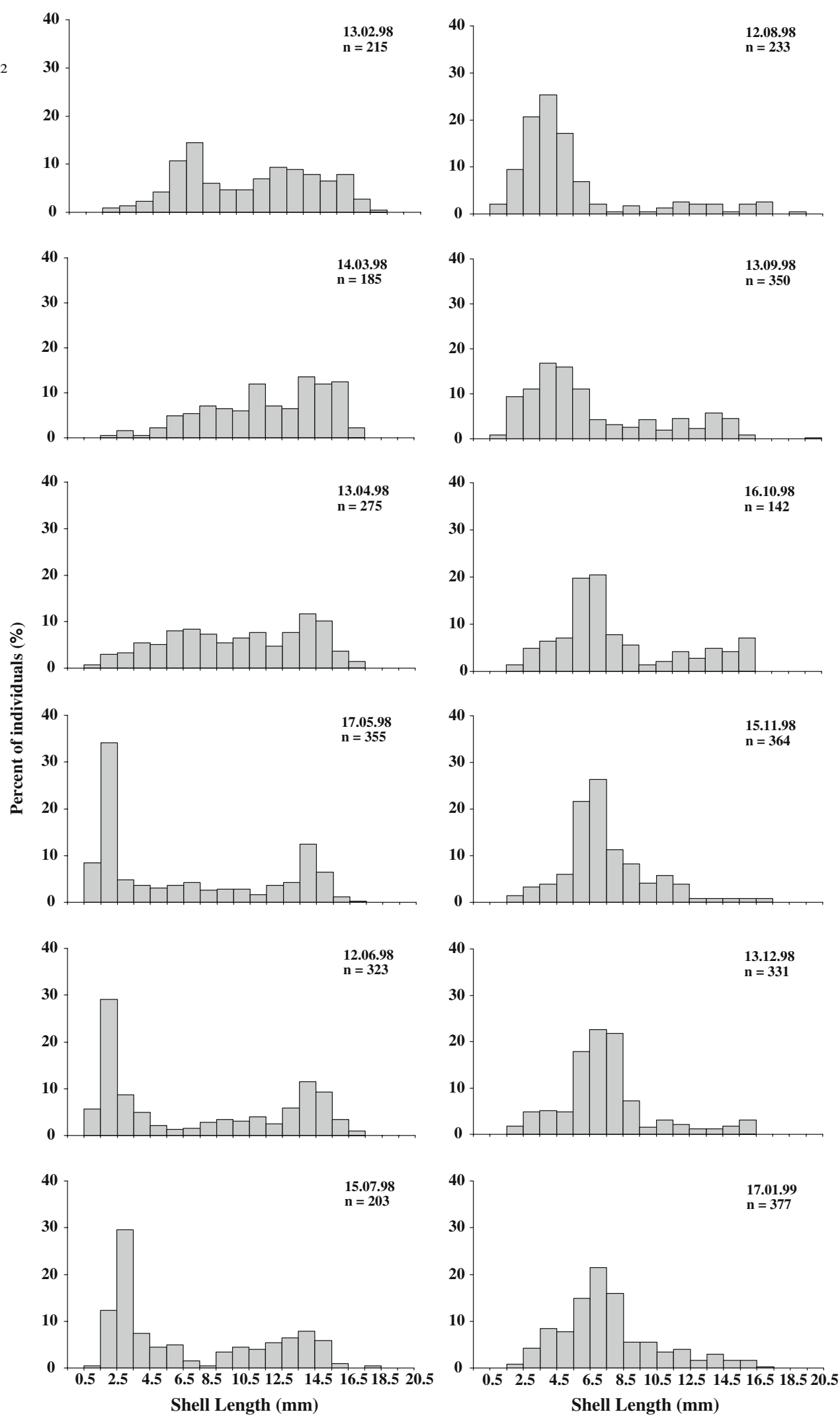

the following period the values of all three environmental variables declined $\left(4.2-8.6^{\circ} \mathrm{C}, 0.7-1.7 \mathrm{psu}\right.$ and 0.82 $0.84 \%$, respectively).
Three size groups $\left(\mathrm{B}_{1}, \mathrm{~B}_{2}, \mathrm{~B}_{3}\right)$, having a comparatively large shell length $(6.2,12.5$ and $15.4 \mathrm{~mm}$, respectively) constituted the entire population in February 1998 (Fig. 2). 
Table 2 Spearman's rank correlation coefficient values between abiotic variables of water and sediment and the percentage of Abra segmentum individuals having a shell length of $\leq 3.5 \mathrm{~mm}\left(\rho_{1}\right)$ or density of A. segmentum $\left(\rho_{2}\right)$ at station $\mathrm{B}_{2}$

\begin{tabular}{lllll}
\hline Variable & $\rho_{1}$ & & $\rho_{2}$ & \\
\hline Water & & & & \\
Salinity (psu) & 0.315 & NS & 0.280 & NS \\
Temperature $\left({ }^{\circ} \mathrm{C}\right)$ & 0.699 & $*$ & 0.035 & NS \\
Sediment & & & & \\
Temperature at $1 \mathrm{~cm}\left({ }^{\circ} \mathrm{C}\right)$ & 0.733 & $*$ & 0.133 & NS \\
Temperature at $5 \mathrm{~cm}\left({ }^{\circ} \mathrm{C}\right)$ & 0.792 & $* *$ & 0.165 & NS \\
Organic matter $(\%)$ & 0.420 & NS & 0.252 & NS \\
\hline
\end{tabular}

$n=12, N S$ not significant

$* P<0.05, * * P<0.01$

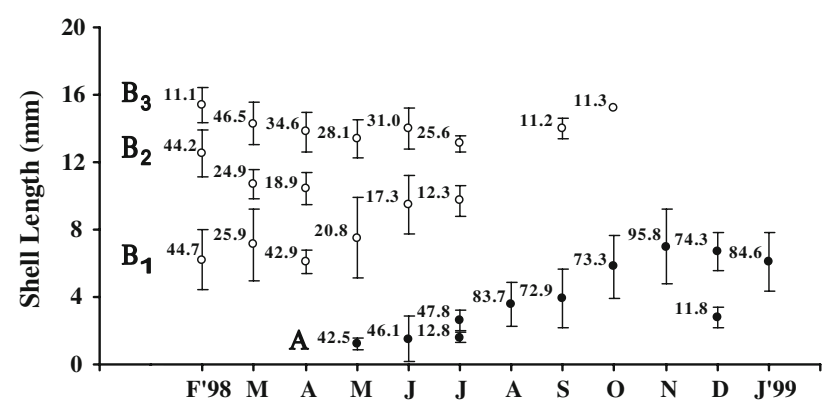

Fig. 2 Development in time of the size groups of Abra segmentum. Dots mean shell length, bar lines standard deviation, numbers percentages of size groups in the total population. Size groups having a participation percentage lower than $10 \%$ were not illustrated

On the other hand, no main size group, except for size group A, was observed after November (Fig. 2). The above suggest that the size groups observed during February to November, except for size group A, composed the age group 1; the apportionment of this age group into size groups must be attributed to the long duration of recruitment as well as to the existence of different rates of growth among the individuals.

Bearing in mind all the above, we can state that recruitment of $A$. segmentum in Monolimni Lagoon mainly occurred from mid-spring to autumn and recruits grew during summer and autumn, while the major part of the individuals vanished during the next autumn displaying a maximum lifespan of a bit less than 20 months.

\section{Population density}

The mean ( \pm standard error) annual density of $A$. segmentum at station $\mathrm{B}_{2}$ was $3,357( \pm 417)$ individuals $\mathrm{m}^{-2}$. Density showed a marked seasonal variation: a sharp increase from
March $\left(1,225\right.$ individuals $\left.\mathrm{m}^{-2}\right)$ to May $(5,263$ individuals $\left.\mathrm{m}^{-2}\right)$ was followed by a sharp decline during July $(2,025$ individuals $\mathrm{m}^{-2}$ ) and afterwards an almost gradual increase up to November $\left(4,813\right.$ individuals $\mathrm{m}^{-2}$; Fig. 3$)$. No significant correlation between density of $A$. segmentum and the examined physico-chemical parameters was found (Table 2). Salinity values during the period of the sharp increase in population density (April-May) varied between 0.3 and $1.2 \mathrm{psu}$, during the period of the second increase (July-November) between 2.8 and 5.7 psu and during the period of the sharp decline (June-July) between 1.3 and 2.8 psu (Table 1$)$.

\section{Length/weight relationship}

The dispersion diagram of $W$ in relation to $L$ for the population of $A$. segmentum at station $\mathrm{B}_{2}$ is shown in Fig. 4. The regression equation was: $\log _{10} W=2.736$ $\log _{10} L-1.928(r=0.976 ; n=1,220)$. A negative allometry exists since $\alpha<3(\alpha \pm \mathrm{SE}=2.736 \pm 0.018, t$ test value $=14.67, P<0.001$ ), which means that the shell length increases faster than the body weight.

\section{Secondary production}

A CPI of about 485 days was estimated (from May to September of the next year, since age group 1 reached the largest size class in September 1998) (Fig. 1). The calculations of the size-frequency method showed that the values of $n$ (mean annual density), $B$ (mean annual crop), $P$ (annual production) and $P / B$ (annual turnover ratio) were 3,357 individuals $\mathrm{m}^{-2}, \quad 21.98 \mathrm{~g} \mathrm{DW} \mathrm{m}{ }^{-2}, 73.72 \mathrm{~g} \mathrm{DW} \mathrm{m}^{-2}$ (after the CPI correction) and 3.35, respectively.

\section{Discussion}

The life history pattern of $A$. segmentum displayed in the oligohaline, semi-enclosed Monolimni Lagoon, being

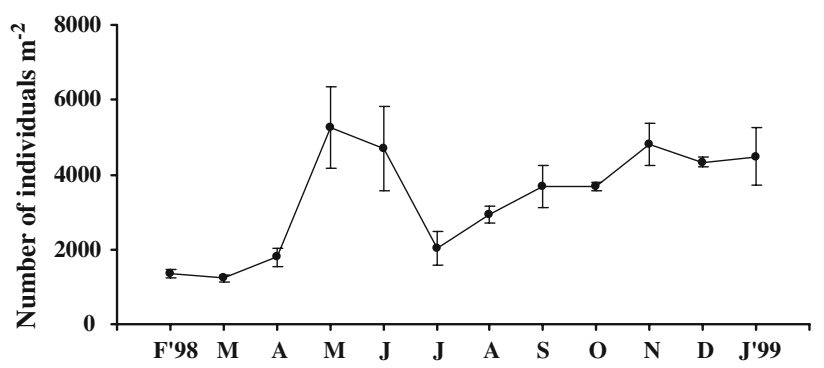

Fig. 3 Monthly variation in population density (mean \pm standard error) of Abra segmentum at station $\mathrm{B}_{2}$ in Monolimni Lagoon 


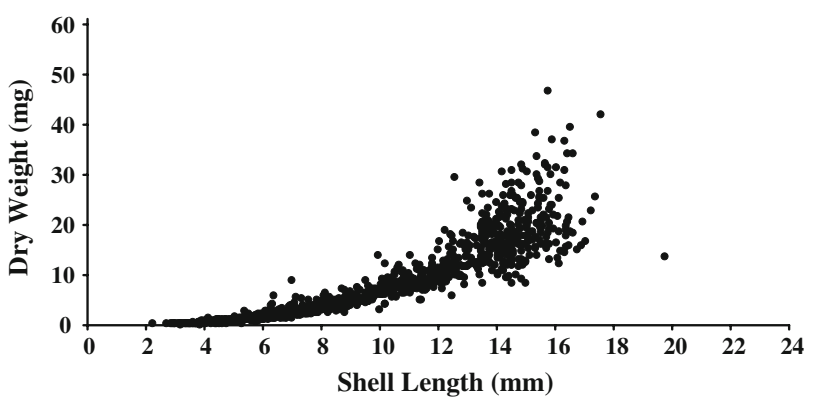

Fig. 4 Dispersion diagram of dry body weight (in $\mathrm{mg}$ ) in relation to shell length (in mm) in 1,220 animals of Abra segmentum

characterized by one annual recruitment with a long duration, the existence of two age groups throughout the major part of the annual cycle and a longevity of about 20 months, was similar to that shown by this species in a poly-euhaline, isolated from the sea area of the Evros River Delta (Kevrekidis and Koukouras 1992). A difference in the timing of recruitment was observed (from mid-spring to autumn in Monolimni Lagoon, from mid-autumn to winter in the isolated area); however, an annual variability, which was attributed to an earlier recruitment during the previous year, existed in the structure of the population from the isolated area (Kevrekidis and Koukouras 1992). Populations of A. segmentum are usually characterized by a local and, perhaps, an annual variability in the timing of recruitment (e.g. Denis 1981; Guelorget and MazoyerMayere 1982; Kevrekidis and Koukouras 1992; Reizopoulou and Nicolaidou 2007), a fact which is probably related to local factors and the geographical variation of physiological properties among populations (Kevrekidis \& Koukouras, 1992).

Recruits of A. segmentum in Monolimni Lagoon may have come from a reproductive activity mainly in spring and summer. The increase in temperature during spring (from about $8^{\circ} \mathrm{C}$ in February-March to about $17^{\circ} \mathrm{C}$ in April-May) most probably favoured the reproductive activity. This is reinforced by the fact that the percentage of the individuals having a shell length of $\leq 3.5 \mathrm{~mm}$ was positively correlated with water and sediment temperature; this is also consistent with previous findings, that is temperatures higher than $8^{\circ} \mathrm{C}$ are favourable to A. segmentum reproductive activity (see Kevrekidis and Koukouras 1992). On the other hand, the extremely low salinities in Monolimni Lagoon during spring (0.3-1.2 psu) obviously did not deter its reproductive activity and subsequent recruitment.

In general, two different life strategies have been reported for A. segmentum. Bachelet et al. (1986) described a life strategy being characterized by a prolonged period of reproduction, development including a short pelagic phase and a long meiobenthic phase (3-6 months), two generations per year and a longevity of 1-2 years; on the other hand, Sprung (1994) reported a mode of life being characterized by a relatively short reproductive period, direct development, a short meiobentic phase, one generation per year and a longevity of 1 year. Reizopoulou and Nicolaidou (2007) suggested that either A. segmentum adopts the former life strategy in confined lagoons and the latter one in coastal habitats having good communication with the sea, or it is a case of sibling species.

The finding that the age group 0 of $A$. segmentum in Monolimni Lagoon showed a constant growth in shell length from late spring to late autumn suggests that the prevailing environmental conditions during this period (e.g. $\left.10-28^{\circ} \mathrm{C}, 1.2-5.7 \mathrm{psu}\right)$ were, at least relatively, favourable for growth. Low temperatures and extremely low salinities $\left(4-8.5^{\circ} \mathrm{C}, 0.7-1.7 \mathrm{psu}\right.$, respectively) during winter might have resulted in the reduction of growth rate because of increased metabolic costs. A possible decline in food availability during winter may have further contributed to this reduction; sediment organic matter, which is a representative index of potential food for deposit-feeding macroinvertebrates, showed intermediate concentrations from late spring to late autumn and lower ones during the rest period of the annual cycle. Taking into account the facts that (1) sediment organic matter showed intermediate concentrations in the study area during the major part of the annual cycle, (2) most probably it was mainly derived from the decomposition of $R$. maritima material, and (3) in experiments, detritus derived from a seagrass was better utilized by $A$. segmentum than that from a seaweed (Charles 1993), and feeding rates of A. segmentum tended to be maximal at intermediate sediment organic concentrations (Grémare et al. 2004), we assume that this bivalve efficiently utilized food sources in the study area.

The growth rate in shell length of the age group 0 of A. segmentum in the Monolimni Lagoon $\left(0.97 \mathrm{~mm} \mathrm{month}^{-1}\right)$ from late spring to late autumn, when salinity varied between 1.2 and $5.7 \mathrm{psu}$, was higher or comparable to those displayed by the same species at higher salinity coastal habitats (0.47-1.10 mm month ${ }^{-1}$, see for review Nicolaidou and Kostaki-Apostolopoulou 1988) as well as under laboratory conditions at $38 \mathrm{psu}$ and $15^{\circ} \mathrm{C}\left(0.60 \mathrm{~mm}\right.$ month $^{-1}$, Frantzis et al. 1993). In addition, the maximum shell length of A. segmentum in the study area $(19.76 \mathrm{~mm})$ is among the largest of those previously reported for this species at higher salinity coastal habitats; in particular, this maximum size varied between 9 and $20 \mathrm{~cm}$ among various populations of A. segmentum (Table 3).

The relation between shell length $(L)$ and dry body weight $(W)$ has been described by an exponential equation $\left(W=b L^{\alpha}\right)$ in other $A$. segmentum populations as well as in other Abra species. The exponent $\alpha$ had a value of 2.74 in 


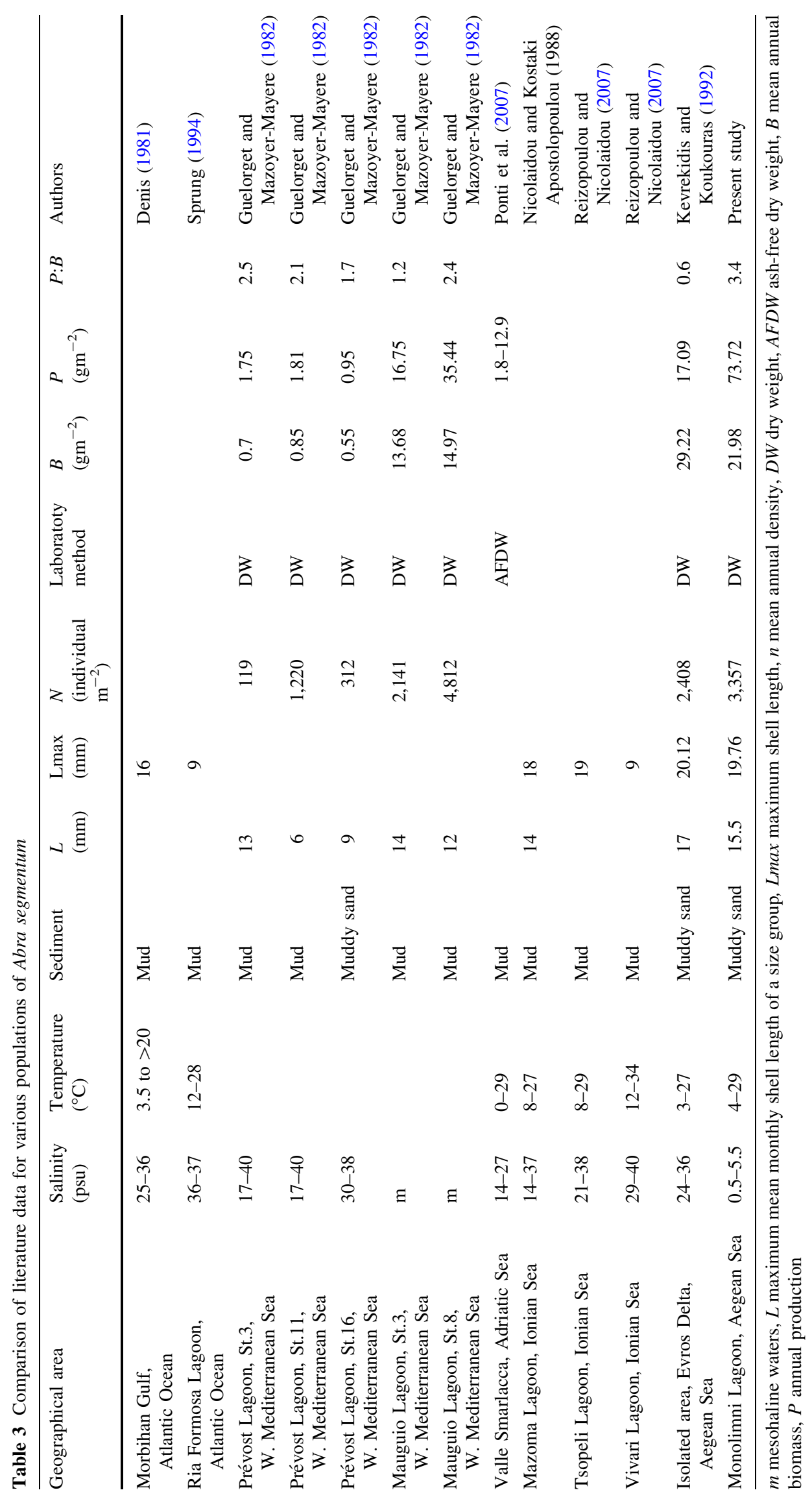


the population of $A$. segmentum in the study area, which approximates 3.0 more than that in a population of the same species in a confined, poly-euhaline habitat in the Evros River Delta $(\alpha=2.35)$. The exponent $\alpha$ varied between 2.5 and 3.3 in other Abra species (e.g. Wikander 1980; Josefson 1982; Dauvin 1986a, b).

The population density of $A$. segmentum in the study area sharply increased during late spring despite the very low salinities $(<1 \mathrm{psu})$, following the recruitment. However, this increase was followed by a continuous decline during summer; predation pressure or/and extreme values of non-examined environmental variables, such as low oxygen concentrations at night due to high temperatures and intensive respiration rhythm of the large amounts of R. maritima (see Cunha and Moreira 1995; Malea et al. 2004), were possibly responsible for this decline. The seasonal dynamics of the macrofaunal assemblage in the study area was found to be mainly governed by the synergistic effect of water temperature, which is associated with the reproductive cycle of the macrobenthic species and predation pressure by crabs and gobies, which showed their highest abundances in May-June (Kevrekidis 2004). Mean annual population density of A. segmentum in Monolimni Lagoon is in the range of those previously reported for other populations of this species from higher salinity habitats (see Table 3 ).

Mean annual biomass $(B)$, annual production $(P)$ and annual turnover ratio $(P / B)$ estimates of $A$. segmentum populations are summarized in Table 3 (different methods were used in the different areas). A comparison between the various populations is difficult due to the different methods used for the estimation of production; nevertheless, it is revealed from Table 3 that $B, P$ and $P / B$ values of $A$. segmentum population in the study area are comparatively high despite the extremely low salinities, as a result of the comparatively high population density, long body size and fast growth of the age group 0 . In addition, $B, P$ and $P / B$ values of $A$. segmentum in Monolimni Lagoon are high, compared to those previously reported for various populations of other Abra species (see for review Kevrekidis and Koukouras 1992; Casagranda and Boudouresque 2005).

In summary, A. segmentum in the oligohaline Monolimni Lagoon displayed a life history pattern similar to that shown in higher salinity habitats: recruitment was first observed in spring and population density sharply increased during this period, despite the extremely low salinities $(<1 \mathrm{psu})$; growth rate of the age group 0 during summer and autumn and the maximum body size were high, compared to those this species displayed at higher salinity habitats, while the exponent $\alpha$ of the relation between shell length and dry body weight approximates 3.0; mean annual density, mean annual biomass $(B)$, annual production $(P)$ and $P: B$ ratio were comparatively high. The above suggest that recruitment, growth, life history pattern, population dynamics and production of $A$. segmentum were not markedly affected by low salinity, refuting our initial hypothesis; a potential efficient utilization of food sources may have enabled $A$. segmentum to maintain a positive energy balance and, thereby, its overall performance.

Acknowledgments Many thanks go to Dr. A. Mogias and Ms T. Boubonari for sampling and laboratory assistance. We would also like to thank the two anonymous referees for their valuable comments on a previous version of the paper.

\section{References}

Aladin NV, Filippov AA, Plotnikov IS, Orlova MI, Williams WD (1998) Changes in the structure and function of biological communities in the Aral Sea, with particular reference to the northern part (Small Aral Sea), 1985-1994: a review. Int J Salt Lake Res 7:301-343

Bachelet G, Bouchet JM, Cornet M, Dauvin JC, Gentil F, Labourg PJ, Madani I (1986) Dynamique comparée de populations du genre Abra (Mollusque Lamellibranche): rôle des contraintes du milieu dans l'acquisition de stratégies démographiques. In: Biologie des populations. Actes Colloque National CNRS, pp 107-115

Casagranda C, Boudouresque CF (2005) Abundance, population structure and production of Scrobicularia plana and Abra tenuis (Bivalvia: Scrobicularidae) in a Mediterranean brackish lagoon, Lake Ichkeul, Tunisia. Int Rev Hydrobiol 90:376-391

Charles F (1993) Utilization of fresh detritus derived from Cystoseira mediterranea and Posidonia oceanica by the deposit-feeding bivalve Abra ovata. J Exp Mar Biol Ecol 174:43-64

Cottiglia M, Tagliasacchi Masala ML, Serra E (1983) Relations trophiques dans une lagune littorale tyrrhenienne. Rapp Comm Int Mer Medit 28:151-153

Cunha MR, Moreira MH (1995) Macrobenthos of Potamogeton and Myriophyllum beds in the upper reaches of Canal de Mira (Ria de Aveiro, NW Porugal): community structure and environmental factors. Neth J Aquat Ecol 29:377-390

Cunha MR, Moreira MH, Sorbe JC (2000) Predicting amphipods' brood size variation in brackish environments: an empirical model for Corophium multisetosum Stock, 1952 (Corophiidae) in Ria de Aveiro (NW Portugal). J Exp Mar Biol Ecol 248:207-223

Dauvin JC (1986a) Biologie, dynamique et production d'une population d' Abra alba (Wood) (Mollusque-Bivalve) de la Baie de Morlaix (Manche occidentale). J Exp Mar Biol Ecol 97:151-180

Dauvin JC (1986b) Dynamique de la population d'Abra prismatica (Mollusque, Bivalve) de la Baie de Morlaix (Manche occidentale). Ann Inst Oceanogr Paris 62:1-12

Denis P (1981) Croissance linéaire, croissance pondérale et période de reproduction de Abra ovata, Mollusque Pélécypode, dans la partie orientale du Golfe du Morbihan. Cah Biol Mar 22:1-9

Frantzis A, Grémare A, Vétion G (1993) Taux de croissance et rapports ARN/ADN chez le bivalve dépositivore Abra ovata nourri à partir de différents détritus. Oceanol Acta 16:303-313

Grémare A, Duchêne JC, Rosenberg R, David E, Desmalades M (2004) Feeding behaviour and functional response of Abra ovata and A. nitida compared by image analysis. Mar Ecol Prog Ser 267:195-208

Guelorget O, Mazoyer-Mayere C (1982) Croissance et production d' Abra ovata dans deux étangs languedociens: l'étang du Prévost et l' étang de Mauguio. Haliotis 12:3-11 
Harding JP (1949) The use of probability paper for the graphical analysis of polymodal frequency distributions. J Mar Biol Ass UK 28:141-153

Josefson AB (1982) Regulation of population size, growth, and production of a deposit-feeding bivalve: a long-term field study of three deep-water populations off the Swedish west coast. J Exp Mar Biol Ecol 59:125-150

Kevrekidis T (2004) Seasonal variation of the macrozoobenthic community structure at low salinities in a Mediterranean lagoon (Monolimni Lagoon, Northern Aegean). Int Rev Hydrobiol 89:407-425

Kevrekidis T, Koukouras A (1992) Population dynamics, growth and productivity of Abra ovata (Mollusca, Bivalvia) in the Evros Delta (North Aegean Sea). Int Revue ges Hydrobiol 77:291-301

Kevrekidis T, Kokkinakis A, Koukouras A (1990) Some aspects of the biology and ecology of Knipowitschia caucasica (Teleostei: Gobiidae) in the Evros Delta (North Aegean Sea). Helgolander Meeresunters 44:173-187

Kiseleva MI, Revkov NK, Kopytov YP (1996) Modern state and long-term changes in zoobenthos of the Streletskaya Bight (Sevastopol Region). Hydrobiol J 33:3-13

Larimore WR (1970) Two shallow-water bottom samplers. The progressive fish culturist, pp 116-118

Latypov YY (2004) Succession in the Abra ovata community on soft grounds of a newly flooded area of the Caspian Sea. Russ J Ecol $35: 267-273$

Maire O, Duchêne JC, Grémare A, Malyuga VS, Meysman FJR (2007) A comparison of sediment reworking rates by the surface deposit-feeding bivalve Abra ovata during summertime and wintertime, with a comparison between two models of sediment reworking. J Exp Mar Biol Ecol 343:21-36

Malea P, Kevrekidis T, Mogias A (2004) Annual versus perennial growth cycle in Ruppia maritima L.: temporal variation in population characteristics in Mediterranean lagoons (Monolimni and Drana Lagoons, Northern Aegean Sea). Bot Mar 47:357-366

Marazanof F (1969) Contribution à l'étude écologique des Mollusques des eaux douces et saumâtres de Camargue I. MilieuxEspèces. Ann Limnol 5:201-323

Menzies CA (1980) A note on the Hynes method of estimating secondary production. Limnol Ocean 25:770-773

Neuparth T, Costa FO, Costa MH (2002) Effects of temperature and salinity on life history of the marine amphipod Gammarus locusta: implications for ecotoxicological testing. Ecotoxicology 11:61-73

Nicolaidou A, Kostaki-Apostolopoulou M (1988) The growth of Abra ovata in a brackish water lagoon. Vie Marine 9:7-10

Nicolaidou A, Petrou K, Kormas KA, Reizopoulou S (2006) Interannual variability of soft bottom macrofaunal communities in two Ionian sea lagoons. Hydrobiologia 555:89-98

Normant M, Lamprecht I (2006) Does scope for growth change as a result of salinity stress in the amphipod Gammarus oceanicus? J Exp Mar Biol Ecol 334:158-163

Ponti M, Colangelo MA, Ceccherelli VU (2007) Composition, biomass and secondary production of the macrobenthic invertebrate assemblages in a coastal lagoon exploited for extensive aquaculture: Valle Smarlacca (northern Adriatic Sea). Estuar Coast Shelf Sci 75:79-89

Reizopoulou S, Nicolaidou A (2007) The growth of the bivalve Abra segmentum (Recluz, 1843) in two Mediterranean lagoons. Transit Waters Bull 4:1-8

Sprung M (1994) Observations on the life cycle of Abra ovata on an intertidal mud flat in Portugal. J Mar Biol Ass UK 74:919-925

Wikander PB (1980) Biometry and behaviour in Abra nitida (Müller) and A. longicallus (Sacchi) (Bivalvia, Tellinacea) Sarsia 65:255268 